\title{
The impact of colorectal chromendoscopy with enhanced mucosal imaging on adenoma miss rate in screening colonoscopy
}

\author{
Bruna Suelen Raymundo LUZ, Juliana Carneiro Cabral Dourado CANTERAS, Karen de Carvalho GON, \\ Maria Luisa de Deus BATISTA, Thomy Jun AHN and Fauze MALUF-FILHO
}

\begin{abstract}
Background - Colonoscopy is the gold standard for the diagnosis and treatment of adenomas. It is related with decreased colorectal cancer incidence and mortality. However, an important problem is missed colorectal adenoma. All efforts should be undertaken to reduce this rate. Enhancing imaging technologies including electronic chromoendoscopy and magnification has been increasingly adopted for improving the colorectal neoplasia detection rate and the detailed study of its surface, as well. I-scan images (Pentax, Tokyo, Japan) provides virtual chromoendoscopy in real-time during the examination to view the surface pattern, highlighting the microvasculature of the neoplastic lesion. The evidence on the impact of the use of I-scan on the colorectal adenoma detection rate is scarce. Objective - To evaluate whether the use of I-scan has impact on the adenoma miss rate (AMR) of screening colonoscopy exams. Methods - Observational and prospective study conducted by monitoring patients over 50 years undergoing colonoscopy. There were two groups: Group 1 - first inspection with standard high-definition white-light (HDWL) followed by a second inspection with I-scan 1; Group 2 - first inspection with I-scan 1 followed by a second inspection with standard HDWL. The primary outcome was the AMR from the first exam, calculated with the number of adenomas detected in the second exam, divided by the total number of adenomas detected in both exams. Results - A total of 85 patients participated in the study. 14 were excluded, with a final sample of 71 patients, in the Group 1, 34 patients, and the Group 2 , 37. A total of 58 adenomas were detected, 40 in the first inspection ( 20 in each group) and 18 in the second inspection in group 1 . The overall AMR was higher for the Group 1 than the Group $2(47.4 \%$ vs $0 \% P=0.0002)$. Conclusion - The use of I-scan 1 during colonoscopy exam reduces the AMR.
\end{abstract} Keywords - Adenoma; colonoscopy; colon; colonic polyps; prospective studies.

\section{INTRODUCTION}

Colorectal cancer $(\mathrm{CRC})$ is a leading cause of cancer-related death worldwide ${ }^{(1,2)}$. Colonoscopy is the gold standard for diagnosing and treating adenomas, leading to decreased colorectal cancer incidence and mortality ${ }^{(3)}$. Adenoma resection can lead to a $53-70 \%$ reduction in CRC mortality rate during the first ten years after colonoscopy ${ }^{(4)}$. However, we also know that lesions can go unnoticed during routine colonoscopy ${ }^{(5)}$.

The primary indicator of colonoscopy quality is the adenoma detection rate (ADR), calculated by the number of patients in which at least one adenoma was found, divided by the total number of patients over 50 years who underwent screening colonoscopy. Thus, physician's efforts and endoscope manufacturers have been focusing to increase ADR. According to Zimmermann-Fraedrich et al. ${ }^{(6)}$, the only way to assess whether these measures are more successful in increasing ADR than conventional state-of-the-art colonoscopies, is to perform randomized controlled trial studies. There are two types of methodologies: one is to perform simple parallel randomized trials with two groups with or without the intervention and ADR as the primary outcome. The other study type is the so-called "tandem study", which includes two colonoscopies with the new and conventional scope in random order. The second pass will reveal adenomas missed by the first one, the so-called adenoma miss rates (AMR). Several reports indicate that the AMR by observing standard high-definition white-light (HDWL) images ranges from $6 \%$ to $60 \%{ }^{(7)}$. There are some risk factors for increasing AMR, such as inadequate preparation, flat polyp morphology, smaller size, and patients with multiple polyps detected within first colonoscopy. There are reports of cancer cases diagnosed between screening colonoscopies, some of which are advanced stages. Thus, detecting adenomas during screening colonoscopy remains the main objective in performing a high-quality exam, and the results suggest need for improvements in colonoscopic technology ${ }^{(2,8,9)}$.

In addition to standard HDWL colonoscopy, enhancing imaging technologies, including chromoendoscopy and magnification, have been increasingly adopted to assist in the accurate diagnosis of colorectal neoplasms ${ }^{(10)}$. Among chromoendoscopy techonologies, narrow band image - NBI (Olympus: Tokyo, Japan), I-scan (Pentax: Tokyo, Japan), blue-laser imaging - BLI-bright, and Linked-color imaging - LCI (Fujifilm: Tokyo, Japan) are currently available $e^{(10-11-12)}$. 
According to Fujishiro and Kodashima (2010) ${ }^{(13)}$, the image processing of I-scan provides enhanced view by a digital image, a software-oriented technology that allows pixel modifications of sharpness, tone, and contrast. This consists of three types of algorithms: Surface enhancement $(\mathrm{SE})=\mathrm{I}$-scan 1 , contrast enhancement $(\mathrm{CE})=\mathrm{I}$-scan 2, and tone enhancement $(\mathrm{TE})=\mathrm{I}$-scan 3.

Few studies aimed to compare the use of digital chromoendoscopy methods versus standard HDWL colonoscopy imaging in the detection of adenomas. Recently, in Brazil, a study determined the positive impact of LCI (Fujifilm) on detecting colorectal adenomas compared with HDWL and BLI-bright (Fujifilm) ${ }^{(14)}$. In a prospective randomized trial, to compare the detection of adenomas by I-scan vs standard HDWL colonoscopy, higher proportions of patients with adenomas were identified in a group that underwent colonoscopy I-scan than in a group evaluated by HDWL colonoscopy ${ }^{(15)}$. In another prospective randomized trial, patients underwent a tandem colonoscopy and concluded that with I-scan technology more adenomas were detected compared with HDWL colonoscopy ${ }^{(7)}$.

Our aim was to evaluate whether processing technology and chromoendoscopy I-scan with algorithm surface enhancement SE (I-scan 1) can impact the AMR, during screening colonoscopy.

\section{METHODS}

In this randomized, controlled trial we enrolled patients aged from 50 to 80 years, underwent screening, tandem colonoscopies at the endoscopy unit of a tertiary hospital in São Paulo-SP (Brazil). The trial was approved by the local an institutional review board (CAAE 08114319.0.0000.5483).

The exclusion criteria were: patients with ASA III or IV ${ }^{(16)}$; with history of inflammatory bowel disease (IBD); with history of colorectal resection; using anticoagulants; and those with inadequate colon preparation (Boston Bowel Preparation Score $\leq 6)^{(17)}$.

We recorded patients' age, sex, indication for the colonoscopy (symptoms investigation, surveillance, or screening), whether there was a family history of colorectal cancer. Antegrade colon preparation with a $10 \%$ mannitol solution was offered to all patients. Anesthesiologists provided deep sedation with propofol and fentanyl. The equipment used was the video colonoscopy (MagniView EC-3890LZi; Pentax Corporation, Tokyo, Japan), high-resolution video processor (Optivista EPK-i7010; Pentax Corporation, Tokyo, Japan), and high-resolution monitor (NDSsi 26 Radiance G2 HB; NDS Surgical Imaging, San Jose, United States of America). The chromendoscopy with surface enhancement (SE) was: I-scan mode 1.

Patients were allocated in two groups, using the electronic randomization method. Group 1: first inspection with standard HDWL followed by a second inspection with I-scan 1; Group 2: the first inspection with I-scan 1 followed by a second inspection with HDWL.

Three physicians performed the colonoscopies, who have routinely used magnification and chromoendoscopy for more than ten years, performing more than 1000 colonoscopies per year, with an overall ADR target above $25 \%$. A minimum withdrawal time of 6 minutes at each step of the two inspections was the target ${ }^{(18)}$.

All detected lesions were resected, either at the first or the second inspection. Only the adenomatous lesions were considered for analysis. The adenomas were evaluated according to size, morphology, location, and histology. The location was distributed over the proximal colon (cecum, ascending colon, hepatic angle, and trans- verse colon) and distal colon (splenic, descending, sigmoid colon, and rectum). The polyps were morphologically classified according to Paris classification ${ }^{(19)}$ and size $(\leq 5 \mathrm{~mm}, 6-9 \mathrm{~mm} \text {, and } \geq 10 \mathrm{~mm})^{(20)}$.

The anatomopathological variables found were classified according to World Health Organization (WHO) ${ }^{(21)}$. Adenomas were separated into non-advanced and advanced ${ }^{(22,23)}$ (TABLE 1).

TABLE 1. Classification of polyps according to the risk of malignancy.

\section{ADVANCED ADENOMA}

Size $\geq 10 \mathrm{~mm}$

hight-grade dysplasia

Villous component

\section{NON-ADVANCED ADENOMA}

Tubular adenoma low-grade dysplasia $<10 \mathrm{~mm}$

By: Modified de Baron et al. ${ }^{(16)}$.

The primary outcome was AMR from first inspection of examination. We calculated this rate by dividing the number of adenomas, detected during the second inspection of examination by the total number of adenomas.

The failure rate in detecting adenoma using HDLW was 30\%, regardless of gender. Thus, $50 \%$ of patients would have at least one adenoma, and participants with adenomas have an average of two adenomas. For this study, the sample size was calculated to compare proportion between two groups (considering that the number of detection with I-scan 1 is greater than the number with HDWL), with the significance of 0.05 , varying the power test $(0.8)$ to detect a 3 -fold reduction in adenoma rates, the study required 69 adenomas per group. Thus, the researchers consider that a sample of 138 patients, which results in an $80 \%$ test power and a clinically relevant difference of $25 \%$, is adequate for the experiment in question - considering a 10\% loss rate. Sample size calculations were based on the simplified assumption of statistical independence among polyps from the same patient and the use of the $\mathrm{X}^{2}$ test.

The mean, standard deviation, minimum, maximum, and quartiles were considered for quantitative variables and frequency tables for qualitative variables. To verify homogeneity between groups 1 and 2, the chi-square test was used for qualitative variables and Student's t-test for quantitative variables. To check the method's effectiveness, numbers of lesions were adjusted using linear model with mixed effects, with groups (1 and 2), chromoendoscopy, and interaction between group and chromoendoscopy being considered fixed effects and patient as effect random. In every study, significance of $P \leq 0.05$ was considered. REDCap platform was used to tabulate data and SPSS v25 software for analysis.

\section{RESULTS}

From June to September 2019, we found 85 patients (38 Male) eligible for the study. Of these, $14(16.5 \%)$ were excluded (FIGURE 1).

Thus, this study included 71 patients who underwent colonoscopy. Of the 71 patients, $32(45 \%)$ were men, ranging from 50 to 79 years, with an average of 64 years. According to age groups, $28 \%$ were from 50 to 60 years old, $53 \%$ from 61 to 70 , and $19 \%$, from 71 and 80 . 


\begin{tabular}{|c|c|c|}
\hline & Assessed for elegibility (n=85) & \\
\hline & Excluded (n=14) & \\
\hline & patients with ASA III or IV (n=7); & \\
\hline & with a history of $\mathrm{IBD}(\mathrm{n}=1)$; & \\
\hline & with a history of colorectal resection $(\mathrm{n}=2)$; & \\
\hline & using anticoagulants (n=1); & \\
\hline & with inadequate colon preparation $(\mathrm{n}=3)$ & \\
\hline & 71 selected patients for colonoscopy & \\
\hline & Randomization & \\
\hline GROUP 1 n=34 & & GROUP $2 \mathrm{n}=37$ \\
\hline 1st Inspection: HDWL & & 1st Inspection: I-scan \\
\hline $\mathrm{AD}$ 1st $=20$ & & $\mathrm{AD}$ 1st $=20$ \\
\hline 2nd Inspection: I-scan & & 2nd Inspection: HDWL \\
\hline $\mathrm{AD} 2 \mathrm{nd}=18$ & & $\mathrm{AD} 2 \mathrm{nd}=0$ \\
\hline $\mathrm{AMR}=\mathrm{AD2nd}=0.47$ & & $\mathrm{AMR}=\mathrm{AD2nd}=0$ \\
\hline AD1st + AD2nd & & AD1st + AD2nd \\
\hline
\end{tabular}

FIGURE 1. Flow diagram of study randomization.

As indicated by the exam, $7(9.8 \%)$ were for symptoms investigation, $24(33.8 \%)$ for surveillance, and $40(56.3 \%)$ for screening. Ten $(14 \%)$ patients had a family history of colorectal cancer. About $16(23 \%)$ of the studied had never undergone a colonoscopy exam (TABLE 2).
The random division of the groups was 34 (48\%) to Group 1: first inspection with HDWL, and the second with I-scan 1, and 37 $(52 \%)$ to Group 2: first inspection with I-scan 1, and the second with HDWL (FIGURE 1).

The cecum was reached in all colonoscopies.

One hundred one lesions were resected and sent for histopathological analysis. Histologically, $41(40.6 \%)$ non-neoplastic polyps, $58(57.4 \%)$ adenomas, and $2(2 \%)$ moderately differentiated adenocarcinomas were detected.

In 31 patients, at least one adenoma was diagnosed, with an average of 1.5 adenomas per patient. Of these, $18(58 \%)$ were women.

According to the adenomas' endoscopic aspects, most were in the proximal colon $(69 \%), 93 \%$ tubular adenoma with low-grade dysplasia, $86 \%$ sessile, $81 \% \leq 5 \mathrm{~mm}$, and $88 \%$ non-advanced adenomas (TABLE 3).

In group 1, 38 adenomas were detected, with 20 adenomas in the first observation (with HDWL) and 18 adenomas in the second (with I-scan 1), representing an overall AMR of 47.4\%. In Group 2,20 adenomas detected in the first observation, and there was no adenoma in the second, with a null missed adenoma rate. The AMR was significantly higher for the group 1 compared to the group 2 $(P=0.0002)$ TABLE 4.

Regarding the adenomas detected in the second inspection, all under the I-scan 1 , there were only $2(11 \%)$ advanced adenomas, one measuring $10 \mathrm{~mm}$ with tubular histology and one with $5 \mathrm{~mm}$ and a villous component, both located in the distal colon. There was no difference between location $(50 \%$ in the distal colon and $50 \%$ in the

TABLE 2. Group comparison (71 patients who underwent colonoscopy).

\begin{tabular}{|c|c|c|c|c|c|c|c|c|}
\hline \multirow{3}{*}{ Characteristics } & & \multicolumn{4}{|c|}{ G.1 } & \multicolumn{2}{|c|}{ G.2 } & \multirow{3}{*}{$P$ value } \\
\hline & & $\mathbf{N}$ & $\%$ & $\mathrm{n}$ & $\%$ & $\mathrm{n}$ & $\%$ & \\
\hline & & 71 & $100 \%$ & 34 & $48 \%$ & 37 & $52 \%$ & \\
\hline \multirow{2}{*}{ Sex } & Female & 39 & $55 \%$ & 18 & $52.9 \%$ & 21 & $56.8 \%$ & \\
\hline & Male & 32 & $45 \%$ & 16 & $47.1 \%$ & 16 & $43.2 \%$ & \\
\hline \multirow[t]{3}{*}{ Indicated by the exam } & & & & & & & & $>0.7$ \\
\hline & Diagnosis & 7 & $10 \%$ & 3 & $8.8 \%$ & 4 & $10.8 \%$ & \\
\hline & Surveillance & 24 & $34 \%$ & 13 & $38.2 \%$ & 11 & $29.7 \%$ & \\
\hline Family history CCR & Yes & 10 & $14 \%$ & 6 & $17.6 \%$ & 4 & $10.8 \%$ & \\
\hline \multirow[t]{3}{*}{ First colonoscopy } & & & & & & & & $>0.8$ \\
\hline & No & 55 & $77 \%$ & 26 & $76.5 \%$ & 29 & $78.4 \%$ & \\
\hline & Yes & 16 & $23 \%$ & 8 & $23.5 \%$ & 8 & $21.6 \%$ & \\
\hline \multirow[t]{3}{*}{ Age } & & & & & & & & $>0.8$ \\
\hline & $50-70$ years & 57 & $80 \%$ & 28 & $80.0 \%$ & 29 & $78 \%$ & \\
\hline & $71-80$ years & 14 & $20 \%$ & 6 & $20.0 \%$ & 8 & $22 \%$ & \\
\hline
\end{tabular}

CCR: cancer colon retal. 
TABLE 3. Characteristics of the 58 resected adenomas.

\begin{tabular}{|c|c|c|c|c|c|c|c|c|c|}
\hline \multirow{3}{*}{ ENDOSCOPIC ASPECTS } & \multicolumn{3}{|c|}{ TOTAL } & \multicolumn{2}{|c|}{ G.2 } & \multicolumn{2}{|c|}{ G.1 } & \multirow{2}{*}{$\begin{array}{c}\mathrm{G} 1 \\
\text { total }\end{array}$} & \multirow{2}{*}{$\begin{array}{c}\text { G1 } \\
\text { AMR }\end{array}$} \\
\hline & $\mathbf{N}$ & $\%$ & 1nd & 1nd & 2 st & 1nd & 2 st & & \\
\hline & 58 & 100 & 40 & 20 & 0 & 20 & 18 & 38 & $47 \%$ \\
\hline \multicolumn{10}{|l|}{ Location } \\
\hline Proximal and transverse colon & 40 & $69 \%$ & 32 & 17 & 0 & 15 & 8 & 23 & $21 \%$ \\
\hline Distal and rectum colon & 18 & $31 \%$ & 8 & 3 & 0 & 5 & 10 & 15 & $26 \%$ \\
\hline \multicolumn{10}{|l|}{ Anatomopathological } \\
\hline Tubular adenoma hight-grade dysplasia & 1 & $2 \%$ & 1 & 1 & 0 & 0 & 0 & 0 & $0 \%$ \\
\hline Adenoma with Villous component & 3 & $5 \%$ & 2 & 0 & 0 & 2 & 1 & 3 & $3 \%$ \\
\hline \multicolumn{10}{|l|}{ The Paris Classification } \\
\hline pedunculated (0-Ip) & 4 & $7 \%$ & 3 & 1 & 0 & 2 & 1 & 3 & $3 \%$ \\
\hline sessile (0-Is) & 50 & $86 \%$ & 33 & 15 & 0 & 18 & 17 & 35 & $45 \%$ \\
\hline $6-9 \mathrm{~mm}$ & 5 & $9 \%$ & 3 & 3 & 0 & 0 & 2 & 2 & $5 \%$ \\
\hline$\geq 10 \mathrm{~mm}$ & 6 & $10 \%$ & 5 & 2 & 0 & 3 & 1 & 4 & $3 \%$ \\
\hline \multicolumn{10}{|l|}{ Adenoma } \\
\hline Non-advanced adenomas & 51 & $88 \%$ & 35 & 17 & 0 & 18 & 16 & 34 & $42 \%$ \\
\hline Advanced adenomas & 7 & $12 \%$ & 5 & 3 & 0 & 2 & 2 & 4 & $5 \%$ \\
\hline
\end{tabular}

AMR: adenoma miss rates.

TABLE 4. Representing an overall adenoma miss rates - AMR $(P=0.0002)$.

\begin{tabular}{lccccc}
\hline GROUPS & 1st & 2nd & N & AMR & $P$ value \\
\hline Total & 40 & 18 & 58 & & 0.0002 \\
1 & 20 & 18 & 38 & $47 \%$ & \\
2 & 20 & 0 & 20 & $0 \%$ & \\
\hline
\end{tabular}

proximal), and almost all were sessile, $<5 \mathrm{~mm}(94 \%)$. In group 1, AMR was also stratified by size: the rate was $3 \%$ for adenomas greater than $10 \mathrm{~mm}, 5 \%$ for those measuring $6-10 \mathrm{~mm}$, and $39 \%$ for those measuring 1-5 mm; by location: $21 \%$ proximal colon, $26 \%$ distal colon and by anatomopathological: $45 \%$ tubular adenoma with low grade dysplasia, 3\% villous component (TABLE 3).

\section{DISCUSSION}

Impact of chromoendoscopy and image magnification on increase ADR or reduce AMR is still a matter of debate because controversial results have been reported ${ }^{(24)}$. Few tandem or parallel studies are using either ADS or AMR as primary outcome to compare digital chromoendoscopy methods versus standard HDWL colonoscopy for adenoma detection. Evidence about the impact of using I-scan (Pentax, Tokyo, Japan) on detection rate of colorectal adenoma is scarce in the literature ${ }^{(10)}$.

In this study, as we used the "tandem" methodology, all patients were subjected to two inspections in a row to define the AMR. Second inspection revealed the AMR, the adenomas lost in the first colonoscopy inspection. The AMR was significantly higher for the group that observed first with HDWL than the group that first observed with I-scan1 ( $47 \%$ vs $0 \%, P=0.0002)$. Our results were similar to Hoffman et al. (2014) $)^{(7)}$, which showed a higher miss rate for adenomas of $62.5 \%$ of white light imaging versus $30 \%$ of I-scan 2 - contrast enhancement, $(P<0.05$, chi-square test) in tandem screening colonoscopies. In our study, we employed the surface enhancement (SE) algorithm or I-scan 1. We believe that I-scan 1 should be preferred method to reduce AMR, following the reasoning that I-scan 1 is recommended for polyp detection while I-scan 2 (contrast enhancement), and I-scan 3 (tone enhancement) should be used for polyp characterization ${ }^{(13)}$ (FIGURE 2).

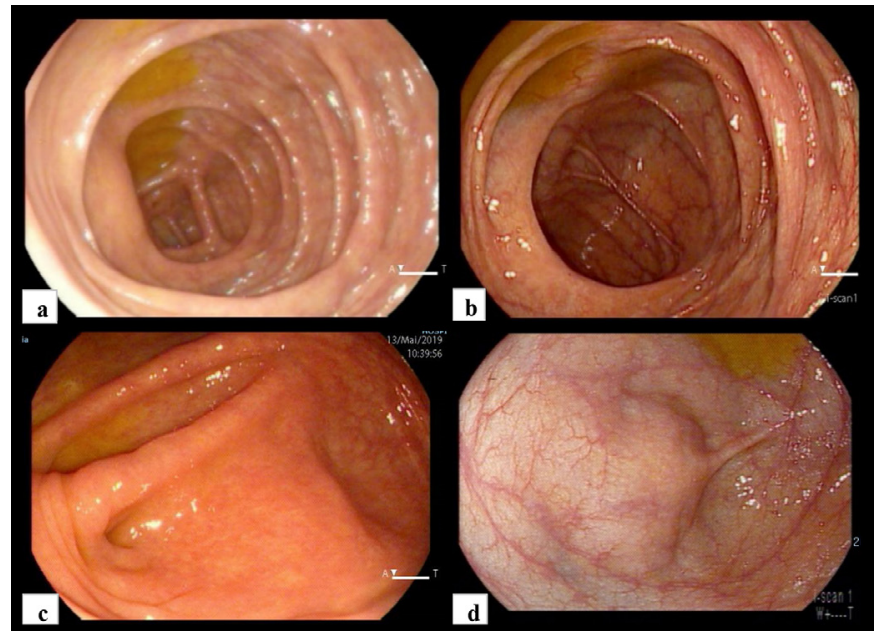

FIGURE 2. Endoscopic aspect of normal mucosa of the right colon. A) ascending colon with HDWL; B) ascending colon with I-scan1; C) cecum with HDLW; D) cecum with I-scan1. 
Not surprisingly, most adenomas missed under HDWL but detected with I-scan 1 were small $(<5 \mathrm{~mm})$, low grade adenomas. In fact, this finding is not different from what is observed when other strategies to increase ADR were adopted: cap $^{(25)}$, retroflexion view of the right colon ${ }^{(26,27)}$, double examination of the right colon ${ }^{(26)}$.

Recently, in Brazil, Santos et al. ${ }^{(14)}$ studied consecutive patients undergoing colonoscopy were randomized (1:1:1) into examination by HDWL, blue-laser imaging (BLI)-bright, or linked-color imaging - LCI (Fujinon) during withdrawal of the colonoscope, and concluded the LCI increases the detection of colorectal adenomas during colonoscopy compared with HDLW. In contrast to our result, using another type of device, Nagorni et al. ${ }^{(28)}$ compared the use of narrow band image - NBI (Olympus) in colonoscopy versus HDWL to detect colorectal adenomas and found no significant difference between the groups. The use of different chromoendoscopy technologies and parallel versus tandem methodology probably accounts for the variation in the results across the studies.

This study has several limitations. We could not reach the calculated sample size of 138 patients. The tandem method has its limitations because it is performed in two moments on the same patient, which can generate anxiety in some patients who refuse to participate in the study. As the study was conducted in a hospital specializing in high complexity, we have many patients with a medical classification ASAIII and IV. Furthermore, we had a limited number of physicians, who were chosen because they have a high
ADR. Thus, given the difficulty in reaching the desired sample, we expanded our inclusion criteria, not only limiting the indication to screening colonoscopy. According to a Zimmermann-Fraedrich $(2020)^{(6)}$ in contrast to the homogeneous performance of parallel studies, tandem trials methodology is more variable with more methodological limitations. However, a review concluded that tandem studies would be associated with significant advantages such as lower sample size ${ }^{(29)}$.

In conclusion, the use of I-scan 1 (surface enhancement) electronic chromoendoscopy, reduced the AMR in screening, surveillance, and diagnostic colonoscopies.

\section{Authors' contribution}

Luz BSR: writing of the text, preparation of the article. Canteras JCCD: study design, data collection, research execution. Gon KC, Ahn TJ and Batista MLD: data collection. Maluf-Filho F: statistical analysis, preparation of the article.

\section{Orcid}

Bruna Suelen Raymundo Luz: 0000-0002-9600-6874.

Juliana Carneiro C Dourado Canteras: 0000-0001-8472-891X.

Karen de Carvalho Gon: 0000-0003-1866-4262.

Maria Luisa de Deus Batista: 0000-0003-1508-4430.

Thomy Jun Ahn: 0000-0001-5669-4732.

Fauze Maluf-Filho: 0000-0001-8875-420X.

Luz BSR, Canteras JCCD, Gon KC, Batista MLD, Ahn TJ, Maluf-Filho F. O impacto da cromoendoscopia com aprimoramento da imagem na taxa de perda de adenoma na colonoscopia de rastreio. Arq Gastroenterol. 2021;58(4):450-5.

RESUMO - Contexto - O câncer colorretal é uma das principais causas de morte relacionada ao câncer em todo o mundo. A colonoscopia é o padrão ouro para diagnosticar e tratar lesões precoces, levando à diminuição da incidência e mortalidade do câncer colorretal. Entretanto, é importante o reconhecimento de que alguns adenomas podem não ser detectados (adenomas perdidos) durante o exame, e todos os esforços vêm sendo destinado a reduzir esta taxa. O aprimoramento das tecnologias de imagem, incluindo cromoendoscopia eletrônica e ampliação, tem sido cada vez mais adotado para melhorar a taxa de detecção de adenomas colorretais. Como exemplo, as imagens obtidas com o I-scan ${ }^{\circledR}$ (Pentax, Tóquio, Japão), que fornecem cromoendoscopia virtual em tempo real durante o exame para visão do padrão de superfície, destacando a microvasculatura da lesão detectada. As evidências sobre o impacto do uso do I-scan ${ }^{\circledR}$ na taxa de detecção de adenoma colorretal são escassas. Objetivo - Avaliar se o uso de imagens I-scan ${ }^{\circledR}$ (Pentax, Tóquio, Japão) tem impacto na taxa de perda de adenoma nas colonoscopias de triagem. Métodos - Estudo observacional prospectivo de colonoscopias comparando cromoscopia com o aprimoramento de superfície e luz-branca. Pacientes acima de 50 anos submetidos à colonoscopia foram alocados aleatoriamente em dois grupos usando randomização eletrônica - Grupo 1: primeira inspeção com luz branca de alta definição seguida por uma segunda inspeção com o aprimoramento de superfície pelo I-scan $1^{\circledR}$; Grupo 2: primeira inspeção com o aprimoramento de superfície I-scan $1^{\circledR}$ seguida de uma segunda inspeção com luz branca de alta definição. O desfecho primário foi a taxa de perda de adenomas do primeiro exame, calculado com o número de adenomas detectados na segunda inspeção do exame dividido pelo número total de adenomas detectados em ambas inspeções. Resultados - Participaram do estudo 85 pacientes, sendo excluídos 14, com amostra final de 71 pacientes. 34 foram alocados para o Grupo 1 e 37 no Grupo 2. Um total de 58 adenomas foram detectados, 40 na primeira inspeção (20 em cada grupo) e 18 na segunda inspeção, somente no Grupo 1. A taxa de perda de adenoma foi maior para o Grupo 1 do que para o Grupo 2 (47,4\% vs $0 \% P=0,0002)$. Conclusão - A utilização de aprimoramento de superfície I-scan 1 reduz a taxa de perda de adenomas em exames colonoscópios.

Palavras-chave - Adenoma; colonoscopia; cólon; pólipo cólico; estudo prospectivo. 


\section{REFERENCES}

1. Siegel R L, Miller K D, Jemal A. Cancer statistics, 2016. CA Cancer J Clin. 2016;66:7-30.

2. Zauber AG, Winawer SJ, O’Brien MJ, Lansdorp-Vogelaar I, van Ballegooijen M, Hankey BF, et al. Colonoscopic polypectomy and long-term prevention of colorectal-cancer deaths. N Engl J Med. 2012;366:687-96. doi: 10.1056/ NEJMoa1100370.

3. Fujimoto D, Muguruma N, Okamoto K, Fujino Y, Kagemoto K, Okada Y, et al. Linked color imaging enhances endoscopic detection of sessile serrated adenoma/polyps. Endosc Int Open. 2018;6:E322-34. doi: 10.1055/s-0043124469

4. Instituto Nacional de Câncer José Alencar Gomes da Silva (INCA). Estimativa. 2016.[Internet] Availble from: https://santacasadermatoazulay.com.br/wp-content/uploads/2017/06/estimativa-2016-v11.pdf

5. Kaminski MF, Regula J, Kraszewska E, Polkowski M, Wojciechowska U, Didkowska J, et al. Quality indicators for colonoscopy and the risk of interval cancer. N Engl J Med. 2010;362:1795-803. doi: 10.1056/NEJMoa0907667.

6. Zimmermann-Fraedrich K, Pohl H, Rösch T, Rex DK, Hassan C, Dekker E, et al. Designs of colonoscopic adenoma detection trials: more positive results with tandem than with parallel studies - an analysis of studies on imaging techniques and mechanical devices. Gut. 2021;70:268-275. doi: 10.1136/gutjnl-2020-320984.

7. Kamiński MF, Hassan C, Bisschops R, Pohl J, Pellisé M, Dekker E, Ignjatovic-Wilson A, Hoffman A, Longcroft-Wheaton G, Heresbach D, Dumonceau JM, East JE. Advanced imaging for detection and differentiation of colorecta neoplasia: European Society of Gastrointestinal Endoscopy (ESGE) Guideline. Endoscopy. 2014;46:435-49. doi: 10.1055/s-0034-1365348.

8. Rex DK, Cutler CS, Lemmel GT, Rahmani EY, Clark DW, Helper DJ, Lehman GA, Mark DG. Colonoscopic miss rates of adenomas determined by backto-back colonoscopies. Gastroenterology. 1997;112:24-8. doi: 10.1016/s00165085(97)70214-2.

9. Heresbach D, Barrioz T, Lapalus MG, Coumaros D, Bauret P, Potier P, et al. Miss rate for colorectal neoplastic polyps: a prospective multicenter study of back-toback vídeo colonoscopies. Endoscopy. 2008;40:284-90. doi: 10.1055/s-2007-995618.

10. Bond A, Burkitt MD, Cox T, Smart HL, Probert C, Haslam N, Sarkar S. Dual-focus Magnification, High-Definition Endoscopy Improves Pathology Detection in Direct-to-Test Diagnostic Upper Gastrointestinal Endoscopy. J Gastrointestin Liver Dis. 2017;26:19-24. doi: 10.15403/jgld.2014.1121.261.gen.

11. Rex DK, Ahnen DJ, Baron JA, Batts KP, Burke CA, Burt RW, et al. Serrated lesions of the colorectum: review and recommendations from an expert panel. Am J Gastroenterol. 2012;107:1315-29. doi: 10.1038/ajg.2012.161.

12. Erichsen R, Baron JA, Hamilton-Dutoit SJ, Snover DC, Torlakovic EE, Pedersen $\mathrm{L}$, et al. Increased risk of colorectal cancer development among patients with serrated polyps. Gastroenterology. 2016;150:895-902.e5. doi: 10.1053/j. gastro.2015.11.046

13. Yamada M, Saito Y, Takamaru H, Sasaki H, Yokota T, Matsuyama Y, et al. Long-term clinical outcomes of endoscopic submucosal dissection for colorectal neoplasms in 423 cases: a retrospective study. Endoscopy. 2017;49:233-242. doi: $10.1055 / \mathrm{s}-0042-124366$
14. Oliveira Dos Santos CE, Malaman D, Pereira-Lima JC, de Quadros Onófrio F, Ribas Filho JM. Impact of linked-color imaging on colorectal adenoma detection. Gastrointest Endosc. 2019;90:826-34. doi: 10.1016/j.gie.2019.06.045

15. Kidambi TD, Bagatelos KC, Ostroff JW. The Answer Is in the Ampulla. Gastroenterology. 2018;155:e13-e14. doi: 10.1053/j.gastro.2018.04.006.

16. American Society of Anesthesiologists Classification. In: StatPearls [Internet]. Treasure Island (FL): StatPearls Publishing; 2020 Dez. Available from: https:// www.ncbi.nlm.nih.gov/books/NBK441940/

17. Lai EJ, Calderwood AH, Doros GD, Fix OK, Jacobson BC. The Boston bowel preparation scale: a valid and reliable instrument for colonoscopy-oriented research. Gastrointest Endosc. 2009;69:620-5. doi: 10.1016/j.gie.2008.05.057.

18. Rex DK, Schoenfeld PS, Cohen J, Pike IM, Adler DG, Fennerty MB, et al. Quality indicators for colonoscopy. Gastrointest Endosc. 2015;81:31-53. doi: 10.1016/j.gie.2014.07.058.

19. The Paris endoscopic classification of superficial neoplastic lesions: esophagus, stomach, and colon: november 30 to december 1, 2002. Gastrointest Endosc. 2003;58(6 Suppl): S3-43. doi: 10.1016/s0016-5107(03)02159-x.

20. Ferlitsch M, Moss A, Hassan C, Bhandari P, Dumonceau JM, Paspatis G, et al. Colorectal polypectomy and endoscopic mucosal resection (EMR): European Society of Gastrointestinal Endoscopy (ESGE) Clinical Guideline. Endoscopy. 2017:49:270-97.

21. Hamilton SR, Aaltonen LA. (Eds.). World Health Organization classification of tumours. pathology and genetics of tumours of the digestive system. Lyon: IARC Press, 2000.

22. Lieberman DA, Rex DK, Winawer SJ, Giardiello FM, Johnson DA, Levin TR. Guidelines for colonoscopy surveillance after screening and polypectomy: a consensus update by the US Multi-Society Task Force on Colorectal Cancer. Gastroenterology. 2012;143:844-57.

23. Baron TH, Smyrk TC, Rex DK. Recommended intervals between screening and surveillance colonoscopies. Mayo Clin Proc. 2013;88:854-8.

24. Hussain $\mathrm{ZH}$, Pohl H. Ancillary imaging techniques and adenoma detection. Gastroenterol. Clin. North Am. 2013;42:547-65.

25. Kondo S, Yamaji Y, Watabe H, Yamada A, Sugimoto T, Ohta M, et al. A randomized controlled trial evaluating the usefulness of a transparent hood attached to the tip of the colonoscope. Am J Gastroenterol. 2007;102:75-81. doi: 10.1111/j.1572-0241.2006.00897.x.

26. Kushnir VA, Barad DH, Gleicher N. Fresh vs Cryopreserved Donor Oocytes--Reply. JAMA. 2015;314:2570. doi: 10.1001/jama.2015.13450.

27. Hewett DG, Rex DK. Miss rate of right-sided colon examination during colonoscopy defined by retroflexion: an observational study. Gastrointest Endosc. 2011;74:246-52. doi: 10.1016/j.gie.2011.04.005.

28. Nagorni A, Bjelakovic G, Petrovic B. Narrow band imaging versus conventional white light colonoscopy for the detection of colorectal polyps. Cochrane Database Syst Rev. 2012;1:CD008361. doi: 10.1002/14651858.CD008361.

29. Van Broek I, Niessen WM, van Dongen WD. Bioanalytical LC-MS/MS of protein-based biopharmaceuticals. J Chromatogr B Analyt Technol Biomed Life Sci. 2013;929:161-79. doi: 10.1016/j.jchromb.2013.04.030

In article The impact of colorectal chromendoscopy with enhanced mucosal imaging on adenoma miss rate in screening colonoscopy, DOI: 10.1590/S0004-2803.202100000-82, published in journal Arq Gastroenterol. 2021;58(4):450-5, in page 454:

\section{Which was read}

O impacto da romoendoscopia com aprimoramento da imagem na taxa de perda de adenoma na colonoscopia de rastreio.

Read

O impacto da cromoendoscopia com aprimoramento da imagem na taxa de perda de adenoma na colonoscopia de rastreio. 